\title{
Graded exposure for fear of pain and movement avoidance belief in chronic low back pain patients
}

\author{
O uso da exposição gradual para a crença de medo da dor e evitação do movimento em \\ pacientes com lombalgia crônica
}

Érica Brandão de Moraes Vieira', Cibele Andrucioli de Mattos Pimenta ${ }^{1}$

DOI 10.5935/1806-0013.20160029

\section{ABSTRACT}

BACKGROUND AND OBJECTIVES: Fear of pain and movement avoidance is a belief contributing to increase disability and mood changes in chronic low back pain patients. Exposure is a technique used for such belief, however there is still no consensus about the best way to perform it in low back pain patients. This study aimed at evaluating graded exposure for fear of pain and movement avoidance belief in chronic low back pain patients.

CONTENTS: The following databases were queried for the period from 2000 to 2015: Pubmed, PsycInfo, Web of Science, Cinahl and LILACS. Eligibility criteria were established for studies selection. Studies were first selected by title and abstract. Then they were read in full. The search has resulted in 91 studies. From these, 38 were selected to be read in full. Among selected studies, 10 were excluded and 19 were repeated. Applying eligibility criteria, nine studies were included: for are before and after studies, one is a case report, one is a quasi-experimental study and three are randomized clinical trials.

CONCLUSION: Most studies of this review have compared in vivo exposure and graded activity, however they have not specified how this was done. There is still no clarity about the advantages or methods to perform graded exposure in low back pain patients and further intervention studies on the subject are needed.

Keywords: Exposure, Fear of pain and movement avoidance, Low back pain.

\section{RESUMO}

JUSTIFICATIVA E OBJETIVOS: Medo da dor e evitação do movimento é uma crença que contribui para o aumento da incapacidade e alteraçóes do humor em pacientes com lombalgia crônica. A exposição é uma técnica utilizada para essa crença, porém ainda não há um consenso sobre a melhor forma de executá-la

1. Universidade de Săo Paulo, Escola de Enfermagem, São Paulo, SP, Brasil.

Submitted in January 30, 2016.

Accepted for publication in May 25, 2016.

Conflict of interests: none - Sponsoring sources: none.

Correspondence to

Av. Dr. Enéas de Carvalho Aguiar, 419

São Paulo, SP, Brasil.

E-mail: enfermeira_erica@yahoo.com.br

(C) Sociedade Brasileira para o Estudo da Dor em pacientes com lombalgia. O objetivo deste estudo foi analisar o uso da exposição graded para a crença de medo da dor e evitação do movimento em pacientes com lombalgia crônica.

CONTEÚDO: Para busca da literatura analisaram-se as bases e bancos de dados Pubmed, PsycInfo, Web of Science, Cinahl e LILACS, no período entre 2000 e 2015. Critérios de elegibilidade foram estabelecidos para seleçáo dos estudos. Os estudos foram selecionados primeiramente a partir do título e resumo. Em seguida foram lidos na íntegra. Resultaram da busca bibliográfica 91 estudos. Destes, 38 foram selecionados para a leitura na íntegra. Entre os selecionados, 10 foram excluídos após leitura na íntegra e 19 estavam repetidos. Aplicando-se os critérios de elegibilidade, restaram 9 estudos, que foram incluídos: quatro são estudos antes e depois, um relato de casos, um é estudo quase experimental e três são ensaios clínicos randomizados.

CONCLUSÁO: A maioria dos estudos desta revisão comparou exposição ao vivo com atividade graded, porém não especificam como foram realizadas. Ainda não há clareza sobre as vantagens ou métodos de como realizar a exposição graded em pacientes com lombalgia, necessitando de maiores estudos de intervenção sobre o tema.

Descritores: Exposição, Lombalgia, Medo da dor e evitação do movimento.

\section{INTRODUCTION}

Cognitive-behavioral factors, such as dysfunctional beliefs, contribute to increased disability and mood changes in chronic low back pain patients ${ }^{1-3}$. Among beliefs considered important to understand low back pain presentations, fear of pain and movement avoidance have been relevant ${ }^{4-9}$.

Fear is an emotional reaction to an immediate, specific and identified threat, aiming at protecting individuals from an imminent danger by promoting self-defense with struggle or escape response ${ }^{10}$. The term kinesiophobia, created in 1990, refers to excessive, irrational and debilitating fear of movement and physical activity, resulting in an erroneous interpretation that movement would worsen the injury or would contribute to the occurrence of new injuries ${ }^{11}$. This idea was first described by Lethem et al. ${ }^{12}$ and Slade et al. ${ }^{13}$, was reformulated in $2000^{14}, 2007^{15}$ and $2013^{8}$ and has become the Fear-Avoidance Model.

The model states that individuals experiencing a painful injury may deal with this in an adaptive or maladaptive way. If injury and painful experience are not perceived as threaten- 
ing, they may be faced and treated adaptatively. Maladaptive coping occurs when, after injury and painful experience, negative cognitions, such as catastrophizing, lead to fear of pain, movement avoidance behaviors, decreased daily activities and increased disability ${ }^{7,14}$. If a previously neuter movement is followed by pain, this will be avoided in the future? ${ }^{9}$. Avoidance behaviors in general become persistent because they occur in response to a future expectation of pain and not necessarily to current pain ${ }^{16}$. Anxiety and hypervigilance are present in such patients ${ }^{9,11}$.

Patients with high fear and movement avoidance are at higher risk of disability and need intervention aiming at changing this belief ${ }^{17}$. There is relationship between fear of pain and movement avoidance and anxiety, depression and disability ${ }^{17-19}$.

A Brazilian cross-sectional study has observed that fear and movement avoidance behavior was a factor associated to increased disability in low back pain patients ${ }^{20}$. Another study has observed that the higher the fear of these patients, the higher the indices of disability, anxiety, depression and fatigue ${ }^{21}$.

There are several intervention studies on fear of pain and movement avoidance with favorable results, however there is still no consensus about the best strategy to be used to change this belief. Graded exposure of low back pain patients consists initially in ranking situations and movements avoided by patients for fear of pain. Then, patients perform movements chosen in the rank in a graded way, that is, starting from the movement causing less fear until the movement of major fear. This graded exposure strategy is already broadly used for phobias, which also involve exaggerated fear ${ }^{22,23,30}$.

Review studies on the subject have found contradictory results and major methodological deficiencies, indicating the need for further investigation $s^{24,25}$. So, expanding existing reviews this study was developed to analyze the effect of graded exposure on fear of pain and movement avoidance beliefs of chronic low back pain patients.

\section{CONTENTS}

For literature search Pubmed, PsycInfo, Web of Science, Cinahl and LILACS databases were analyzed between 2000 and
2015. The following research question was used for this study: "Which is the effect of graded exposure intervention on fear of pain and movement avoidance belief in chronic low back pain patients?"

Search strategy was developed according to PICO strategy concepts, acronym for Patient, Intervention, Comparison and Outcomes, which involves the fundamental elements of the search question, resulting in a more refined search focused on the objectives ${ }^{26}$. PICO strategy for this question is applied as follows:

P: chronic low back pain patients; I: Graded exposure; C: there is no; $\mathbf{O}$ : Fear of pain and movement avoidance.

Search was carried out with controlled and uncontrolled descriptors. Boolean operators AND and OR were used.

Search strategy was: ("Back Pain" [Mesh] OR "Low Back Pain"[Mesh])AND ("Virtual Reality Exposure Therapy"[Mesh] OR "Implosive Therapy"[Mesh] OR "exposure"[All Fields]) AND ("fear-avoidance"[All Fields] OR "fear avoidance"[All Fields] OR "fear-avoidance belief" [All Fields] OR "fear avoidance belief"[All Fields] OR "fear-avoidance attitude"[All Fields] OR "fear avoidance attitude"[All Fields] OR "fearavoidance model" [All Fields] OR "fear avoidance model" [All Fields] OR "kinesiophobia"[All Fields] OR "pain-related fear" [All Fields] OR "pain related fear"[All Fields] OR "fear of pain"[All Fields] OR "Fear"[Mesh]").

Inclusion criteria were studies with adult patients with chronic low back pain, who used graded exposure intervention and had as primary or secondary outcome fear of pain and movement avoidance. These could be case series, before-and-after studies and clinical trials, in English, Spanish and Portuguese. Studies were initially selected by title and abstract. Then they were read in full. Search resulted in 91 studies. From these, 38 were selected to be read in full. Among selected articles, 10 were excluded after reading in full and 19 were repeated. Applying eligibility criteria, 9 studies remained and were included. From these 9 studies, four are before-and-after studies, one case report, one is a quasi-experimental study and three are randomized clinical trials, being that one clinical trial is also a multicenter study. Summary of evaluated studies is shown in table 1.

Table 1. Evaluated studies

\begin{tabular}{|c|c|c|c|c|c|c|c|c|}
\hline Study data & $\begin{array}{l}\text { Study de- } \\
\text { sign }\end{array}$ & Objective & $\mathrm{N}^{\circ}$ & $\begin{array}{l}\text { of evaluation } \\
\text { tools }\end{array}$ & Outcomes & $\begin{array}{l}\text { Sessions/du- } \\
\text { ration }\end{array}$ & Interventions & Results \\
\hline $\begin{array}{l}\text { Vlaeyen et } \\
\text { al. }{ }^{11}\end{array}$ & $\begin{array}{l}\text { B efore- } \\
\text {-and-after } \\
\text { with cros- } \\
\text { sover }\end{array}$ & $\begin{array}{l}\text { To examine the } \\
\text { effectiveness of } \\
\text { in vivo exposure } \\
\text { and compare with } \\
\text { graded activity to } \\
\text { decrease fear of } \\
\text { pain and movement } \\
\text { avoidance, catas- } \\
\text { trophizing and disa- } \\
\text { bility in chronic low } \\
\text { back pain patients } \\
\text { with high fear of } \\
\text { pain and movement } \\
\text { avoidance. }\end{array}$ & 4 & $\begin{array}{l}\text { TSK } \\
\text { PASS } \\
\text { PCS } \\
\text { EAV } \\
\text { PCL } \\
\text { RDQ }\end{array}$ & $\begin{array}{l}\text { Fear of pain and mo- } \\
\text { vement avoidance } \\
\text { Anxiety } \\
\text { Catastrophizing }\end{array}$ & $\begin{array}{l}\text { Not mentio- } \\
\text { ned }\end{array}$ & $\begin{array}{l}\text { In vivo exposure } \\
\text { followed of gra- } \\
\text { ded activity } \\
\text { Graded activity } \\
\text { followed by in } \\
\text { vivo exposure }\end{array}$ & $\begin{array}{l}\text { There has been impro- } \\
\text { vement only during in } \\
\text { vivo exposure and not } \\
\text { during graded exposure, } \\
\text { regardless of the order } \\
\text { of treatment. } \\
\text { Analysis of pre and post- } \\
\text {-treatment differences } \\
\text { has shown that decrea- } \\
\text { sed fear and movement } \\
\text { avoidance were related } \\
\text { to pain, disability and } \\
\text { catastrophizing decrea- } \\
\text { se in half the cases. }\end{array}$ \\
\hline
\end{tabular}


Table 1. Evaluated studies - continuation

\begin{tabular}{|c|c|c|c|c|c|c|c|c|}
\hline Study data & $\begin{array}{l}\text { Study de- } \\
\text { sign }\end{array}$ & Objective & $\mathrm{N}^{\circ}$ & $\begin{array}{l}\text { of evaluation } \\
\text { tools }\end{array}$ & Outcomes & $\begin{array}{l}\text { Sessions/du- } \\
\text { ration }\end{array}$ & Interventions & Results \\
\hline $\begin{array}{l}\text { de Jong et } \\
\text { al. }^{3}\end{array}$ & $\begin{array}{l}\text { B e fore- } \\
\text { and-after }\end{array}$ & $\begin{array}{l}\text { To examine the } \\
\text { contribution of edu- } \\
\text { cation and graded } \\
\text { exposure, com- } \\
\text { pared to education } \\
\text { and graded activity } \\
\text { to decrease fear of } \\
\text { pain and movement } \\
\text { avoidance and as- } \\
\text { sociated to dis- } \\
\text { ability and physical } \\
\text { activity. }\end{array}$ & 6 & $\begin{array}{l}\text { TSK } \\
\text { PVAQ } \\
\text { Roland Disa- } \\
\text { bility Questio- } \\
\text { nnaire } \\
\text { Activity Mo- } \\
\text { nitor } \\
\text { PASS } \\
\text { PCS } \\
\text { VAS } \\
\text { PHODA }\end{array}$ & $\begin{array}{l}\text { Fear of pain and mo- } \\
\text { vement avoidance } \\
\text { Vigilance of pain } \\
\text { Pain intensity } \\
\text { Disability } \\
\text { Level of activity }\end{array}$ & $\begin{array}{l}\text { Ed uc a tion } \\
\text { and exposure } \\
\text { group: } 7 \text { ses- } \\
\text { sions } \\
\text { Ed uc a ti on } \\
\text { and gra- } \\
\text { ded activity } \\
\text { group: } 9 \text { ses- } \\
\text { sions }\end{array}$ & $\begin{array}{l}\text { Education } \\
\text { Exposure } \\
\text { Graded activity }\end{array}$ & $\begin{array}{l}\text { Results were better } \\
\text { when education came } \\
\text { before in vivo exposure } \\
\text { with regard to graded } \\
\text { activity program } \\
\text { Activities performance } \\
\text { was not affected by edu- } \\
\text { cational session and has } \\
\text { significantly improved } \\
\text { only with in vivo expo- } \\
\text { sure }\end{array}$ \\
\hline Linton et al. ${ }^{28}$ & $\begin{array}{l}\text { Random- } \\
\text { ized clini- } \\
\text { cal trial } \\
\text { with cross- } \\
\text { over }\end{array}$ & $\begin{array}{l}\text { To examine the ef- } \\
\text { fectiveness of grad- } \\
\text { ed exposure in vivo } \\
\text { on fear of pain and } \\
\text { movement avoid- } \\
\text { ance and disability } \\
\text { in chronic low back } \\
\text { pain patients }\end{array}$ & 46 & $\begin{array}{l}\text { OMPSQ } \\
\text { TKS } \\
\text { PCS } \\
\text { PHODA - au- } \\
\text { thors used } 40 \\
\text { photos }\end{array}$ & $\begin{array}{l}\text { Fear of pain and mo- } \\
\text { vement avoidance } \\
\text { Disability } \\
\text { Pain } \\
\text { Perception of loss }\end{array}$ & $\begin{array}{l}2 \text { sessions } \\
\text { per week for } \\
8 \text { weeks } \\
\text { After the } 14^{\text {th }} \\
\text { week there } \\
\text { was a cros- } \\
\text { sover betwe- } \\
\text { en groups }\end{array}$ & $\begin{array}{l}\text { Graded in vivo } \\
\text { exposure } \\
\text { Waiting list }\end{array}$ & $\begin{array}{l}\text { Comparison between } \\
\text { groups has shown signi- } \\
\text { ficant results with regard } \\
\text { to functionality for the } \\
\text { exposure group, but not } \\
\text { for fear and pain } \\
\text { When the control group } \\
\text { received the interven- } \\
\text { tion, after the crossover } \\
\text { there were significant } \\
\text { results for functionality, } \\
\text { fear and pain. } \\
\text { Exposure had better } \\
\text { results in the group re- } \\
\text { ceiving usual assistance } \\
\text { first. }\end{array}$ \\
\hline
\end{tabular}


Table 1. Evaluated studies - continuation

\begin{tabular}{|c|c|c|c|c|c|c|c|c|}
\hline Study data & $\begin{array}{l}\text { Study de- } \\
\text { sign }\end{array}$ & Objective & $\mathrm{N}^{\circ}$ & $\begin{array}{l}\text { of evaluation } \\
\text { tools }\end{array}$ & Outcomes & $\begin{array}{l}\text { Sessions/du- } \\
\text { ration }\end{array}$ & Interventions & Results \\
\hline Leeuw et al. ${ }^{6}$ & $\begin{array}{l}\text { Randomi- } \\
\text { zed mul- } \\
\text { ticenter } \\
\text { clinical trial }\end{array}$ & $\begin{array}{l}\text { To evaluate the } \\
\text { effectiveness of } \\
\text { exposure versus } \\
\text { graded activity in } \\
\text { chronic low back } \\
\text { pain patients and } \\
\text { moderate fear of } \\
\text { pain and movement } \\
\text { avoidance. }\end{array}$ & 85 & $\begin{array}{l}\text { Quebec Pain } \\
\text { D is a b i I it y } \\
\text { Scale; } \\
\text { Patient Speci- } \\
\text { fic Complains } \\
\text { PHODA -SeV } \\
\text { TSK } \\
\text { Catastrophic } \\
\text { thoughts sca- } \\
\text { le } \\
\text { McGill Pain } \\
\text { Questionnaire }\end{array}$ & $\begin{array}{l}\text { Disability } \\
\text { Physical activities } \\
\text { Fear } \\
\text { Cat a strophizing } \\
\text { thoughts } \\
\text { Pain intensity }\end{array}$ & $\begin{array}{l}2 x \text { per week } \\
\text { lasting } 1 \mathrm{~h} \\
16 \text { sessions } \\
\text { graded ex- } \\
\text { posure group } \\
\text { and } 26 \text { ses- } \\
\text { sions graded } \\
\text { activity group }\end{array}$ & $\begin{array}{l}\text { Graded activity } \\
\text { Graded exposure }\end{array}$ & $\begin{array}{l}\text { Exposure has decreased } \\
\text { pain catastrophizing and } \\
\text { perception of damage } \\
\text { caused by activities; } \\
\text { There has been no diffe- } \\
\text { rence between groups } \\
\text { with regard to disability, } \\
\text { pain intensity and daily } \\
\text { activity level; } \\
\text { Half the patients impro- } \\
\text { ved disability } \\
\text { Exposure effect was } \\
\text { mediated by decreased } \\
\text { catastrophizing and los- } \\
\text { ses perceived during } \\
\text { activities. } \\
\text { During } 6 \text { months of } \\
\text { follow-up there have } \\
\text { been no differences } \\
\text { between exposure and } \\
\text { graded activity groups. }\end{array}$ \\
\hline $\begin{array}{l}\text { George \& } \\
\text { Zeppieri²9 }^{29}\end{array}$ & $\begin{array}{l}\text { Case re- } \\
\text { ports }\end{array}$ & $\begin{array}{l}\text { To describe graded } \\
\text { exposure applied to } \\
\text { physiotherapy }\end{array}$ & 2 & $\begin{array}{l}\text { N u m e ric al } \\
\text { scale } \\
\text { FDAQ } \\
\text { FABQ } \\
\text { Oswestry Di- } \\
\text { sability ques- } \\
\text { tionnaire }\end{array}$ & $\begin{array}{l}\text { Disability } \\
\text { Fear and avoidance } \\
\text { Anxiety } \\
\text { Pain }\end{array}$ & $\begin{array}{l}3 \text { sessions/ } 3 \\
\text { weeks }\end{array}$ & $\begin{array}{l}\text { Education to de- } \\
\text { crease fear and } \\
\text { threat associated } \\
\text { to low back pain } \\
\text { Graded exposure }\end{array}$ & $\begin{array}{l}\text { There has been decrea- } \\
\text { se in fear, pain intensity } \\
\text { and disability scores. }\end{array}$ \\
\hline Georgeet al. ${ }^{23}$ & $\begin{array}{l}\text { Quasi- ex- } \\
\text { perimental }\end{array}$ & $\begin{array}{l}\text { To compare pain } \\
\text { and disability in pa- } \\
\text { tients receiving gra- } \\
\text { ded exercise and } \\
\text { graded exposure. } \\
\text { To investigate whe- } \\
\text { ther changes in fear } \\
\text { of pain and move- } \\
\text { ment avoidance } \\
\text { and catastrophizing } \\
\text { are associated to } \\
\text { changes in pain } \\
\text { scores and disabi- } \\
\text { lity. }\end{array}$ & 33 & $\begin{array}{l}\text { Num e ric al } \\
\text { scale } \\
\text { Oswestry Di- } \\
\text { sability ques- } \\
\text { tionnaire } \\
\text { Fear of pain } \\
\text { questionnaire } \\
\text { FABQ } \\
\text { TSK } \\
\text { FDAQ } \\
\text { Coping stra- } \\
\text { tegies ques- } \\
\text { tionnaire } \\
\text { Beck depres- } \\
\text { sion inventory }\end{array}$ & $\begin{array}{l}\text { Pain } \\
\text { Disability } \\
\text { Fear of pain and mo- } \\
\text { vement avoidance } \\
\text { Catastrophizing } \\
\text { Depression }\end{array}$ & $\begin{array}{l}3 \text { to } 5 \text { weeks } \\
7 \text { hours per } \\
\text { day }\end{array}$ & $\begin{array}{l}\text { Physiotherapy } \\
\text { with graded exer- } \\
\text { cise } \\
\text { Physiotherapy } \\
\text { with graded ex- } \\
\text { posure }\end{array}$ & $\begin{array}{l}\text { Both groups had decre- } \\
\text { ased pain and disability } \\
\text { scores } \\
\text { Fear evaluation tools } \\
\text { have not shown statis- } \\
\text { tically significant decre- } \\
\text { ase. } \\
\text { Catastrophic thoughts } \\
\text { and depression were de- } \\
\text { creased in both groups. } \\
\text { There has been positive } \\
\text { correlation ( } r=0.56 \text { ) be- } \\
\text { tween pain intensity and } \\
\text { depressive symptoms. } \\
\text { There has been positive } \\
\text { correlation between di- } \\
\text { sability and catastrophi- } \\
\text { zing ( } r=0.65 \text { ) }\end{array}$ \\
\hline
\end{tabular}

$\overline{\text { FABQ }}$ = Fear Avoidance Beliefs Questionnaire; TSK = Tampa Scale for Kinesophobia; HADS = Hospital Anxiety and Depression Scale; PHODA = The Photograph Series of Daily Activities; PASS = Pain Anxiety Symptoms Scale; PCS = Pain Catastrophizing Scale; FDAQ = Fear of Daily Activities Questionnaire; VAS = visual analog scale; PCL = Pain Cognition List; RDQ = Roland Disability Questionnaire; PVAQ = Pain Vigilance and Awareness Questionnaire; PIRS = Pain and Impairment Relationship Scale; OMPSQ = Orebro Musculoskeletal Pain Screening Questionnaire.

\section{DISCUSSION}

Before-and-after studies with crossover among participants, aimed at comparing the effects of graded exposure technique and graded activity technique in chronic low back pain patients ${ }^{2,11}$. In all studies, there was a single education session where pain was analyzed as a common condition which could be managed by patients. Then, explanations were given about fear of pain and movement avoidance vicious cycle. Education effectiveness was not evaluated in such studies and was equally offered to all groups. Two studies have used cutoff point above 40 in the Tampa Scale for Kinesiophobia to select patients with higher fear of pain and movement avoidance. Both studies used photos from the Photograph Series of Daily Activities (PHODA) to rank fear, where patients ranked movements represented by the photos which they considered would damage their spine $e^{2,11}$.

The first study, with four patients ${ }^{11}$, has compared the effects of graded exposure followed by graded activity and in a second moment the same interventions in inverted order, on fear of pain and movement avoidance, anxiety, disability and catastrophic thoughts. Graded activity is different from graded exposure for using individual exercises performed according to functional capacity and not according to fear ranking $^{2,30}$. Results have shown that fear of pain and movement avoidance were decreased after graded exposure, regardless of interventions order. There has also been improvement in pain intensity, pain control, catastrophic thoughts and disability with the exposure intervention.

The same study was replicated with six patients, also with 
chronic low back pain and high fear of pain and movement avoidance. Patients were submitted to one of two intervention sequences: graded exposure followed by graded activity or graded activity followed by graded exposure. Results were the same of previous study: fear of pain and movement avoidance improvement after graded exposure, regardless of treatment order. Graded exposure has also improved pain intensity, disability and physical activity. Improvements remained after one year of follow-up ${ }^{2}$.

Another before-and-after study has investigated the effects of in vivo exposure in six patients with high fear of pain and movement avoidance. Initially educative sessions were held to explain the model and cycle of fear of pain and movement avoidance and then effects of in vivo exposure were tested on fear of pain and movement avoidance, pain and functionality beliefs. Fear of movement was ranked with PHODA. Results have shown 54 to $100 \%$ reduction on fear of pain and movement avoidance scores and $50 \%$ on PHODA scores. Patients improved functionality and had mild pain intensity decrease. The three analyzed studies ${ }^{2,11,27}$ were before-and-after studies (without control group), with convenience sample of four to six patients. An education session has always preceded in vivo exposure or graded activity and so there is no analysis showing the isolated effect of education. There are major weaknesses in such studies design.

The first study evaluating the effects of education on graded exposure and activity was published in 2005. This is a beforeand-after study with six patients divided in two groups. One group received education and graded exposure and the other education and graded activity. Education consisted of one session focused on increasing patient's willingness to engage in activities avoided for a long period and on correcting wrong interpretations and concepts which occurred during the development of fear of pain and movement avoidance. Evaluated variables were fear of pain and movement avoidance, pain intensity, disability and daily activity level. Evaluations before and after educative intervention have shown decreased fear of pain and movement avoidance and of catastrophizing after education session for both groups.

Only daily activity level was not changed by educational session and only significantly improved when in vivo exposure was performed after education. Results have shown improvement in all variables in the group receiving education and in vivo exposure, which was not true for the group receiving graded activity ${ }^{3}$.

This before-and-after study design, the convenience sample, the small sample size (six patients) and no blinding when evaluating outcomes, weaken this study results.

The first randomized clinical trial using graded exposure in low back pain patients was published in 2008. In addition, this was the only study using self-efficacy belief as one outcome, together with the belief of fear of pain and movement avoidance. In this study, 83 patients were randomized in three groups: in vivo graded exposure, graded activity and waiting list. Primary outcome was disability. Other evaluated secondary effects were self-efficacy and fear of pain and movement avoidance, anxiety, depression, painful experience and catastrophic thoughts. Graded activity involved the development of healthy behaviors through positive reinforcement of predefined activities.

Graded exposure was performed in eight sessions lasting four weeks. In the first session, an interview was carried out and patients received education about the belief of fear of pain and movement avoidance and about formulation of problems in this context. Still in this session, activities feared by patients and fear of movement by means of PHODA were evaluated. From the second to the fifth session, graded exposure or graded activity were performed; final sessions, from the sixth to the eight, were used to evaluate treatment process and to give patients orientations about preventing relapses. It was observed that the exposure group had significantly better results in all analyzed variables as compared to the graded activity and waiting list groups ${ }^{16}$.

Some important considerations about self-efficacy and fear of pain and movement avoidance beliefs were clarified by this study. Authors have observed that both self-efficacy and fear of pain and movement avoidance are related to disability in chronic low back pain patients. It is supposed that selfefficacy improvement in the exposure group was due to the fact that patients faced feared movements in a successful way, which has promoted a mastery experience for these patients. Decreased fear of pain and movement avoidance, possibly as consequence of exposure, allowed patients exposed to feared activities to become more confident on their ability to perform such movements, which might be the reason for the readjustment of their beliefs. Reduction in the perception of threat by performing feared activities and the disconfirmation of negative beliefs have probably resulted in improved pain, hypervigilance behavior, feeling of threat, decreased anxiety and catastrophizing ${ }^{16}$.

This study was better than the others due to randomization, control group, sample size and better description of the education session, but there has been no analysis allowing the observation of the isolated effect of the education session.

Another clinical trial with crossover, also published in 2008, has compared usual assistance followed by graded exposure and graded exposure followed by usual assistance on disability related to labor activities in 46 patients with chronic low back pain, reduced function and fear of pain and movement avoidance. Participants were randomized in two groups: exposure and usual assistance and outcomes were fear of pain and movement avoidance, perception of loss, pain and disability. Results have shown that variables pain, fear of pain and movement avoidance have improved in the group receiving usual assistance first, followed by exposure, but not in the group receiving the inverse order of assistance. Authors have concluded that exposure was effective only when associated to usual assistance ${ }^{28}$. In this study ${ }^{28}$ it is not clear what authors consider usual assistance. It is not known whether all patients received the same assistance or what was this usual assistance. Another weakness of the study is the lack of a control group to compare effects. 
A randomized multicenter clinical trial carried out in different places in the Netherlands has evaluated the effectiveness of in vivo exposure versus graded activity in chronic low back pain patients. Eighty-five patients with chronic low back pain and moderate to severe fear of pain and movement avoidance were randomized in two groups. Primary outcomes were disability and the perception of damage caused by physical activities. Secondary outcomes were fear of pain and movement avoidance, catastrophic thoughts and pain intensity. Sessions were carried out twice a week in a total of 16 sessions for the exposure group and 26 sessions for the graded activity group. Results have shown further reduction in catastrophizing and perception of loss in the exposure group. Approximately half the patients of both groups have improved disability.

There has been no difference between groups in disability and pain intensity. In six months of follow up, exposure was not more effective than graded activity with regard to outcomes ${ }^{6}$. In this study ${ }^{6}$, the design, number of sessions both for the graded exposure and the graded activity group was superior as compared to previous studies, and the number of sessions for the graded activity group was much higher than for the exposure group. This suggests that it is not clear which is the best "dose" of these interventions to improve self-efficacy and fear of pain and movement avoidance beliefs, and disability in chronic low back pain patients. This is the first study showing the non-superiority of graded exposure over graded activity in six months of follow up.

Last two published studies presented a clinical approach which to date had not been given by previous studies. In addition, the ten situations of the Fear Daily Activities Questionnaire (FDAQ) tool, which had not been used so far, were used to rank fear ${ }^{23,29}$.

In a case report, two patients were evaluated while performing lumbar spine movements and stabilization tests and received as intervention stabilization exercises and graded exposure. Fear was ranked by means of the ten movements of the FDAQ tool in a numeric scale from zero to 100 . Then two movements with scores equal to or above 40 were selected. There has been reduction in fear, pain intensity and disability scores for both patients ${ }^{29}$.

A quasi-experimental study with 33 chronic low back pain patients who received physiotherapy associated to graded exposure or physiotherapy associated to graded exercise, has compared outcomes fear, disability and fear of pain and movement avoidance. The program had 12 blocks of 7 daily hours and has varied from three to five weeks. Patients also received psychological therapy, biofeedback and medical follow up. Psychological treatment focused on decreasing fear and catastrophizing, changing dysfunctional responses with regard to pain and using adaptative coping strategies. For exposure, patients ranked the ten FDAQ situations in a numeric scale from zero to 100 , and have selected two activities with the highest scores.

There has been no post-test difference for both groups with regard to fear of pain and movement avoidance. Both groups have decreased pain intensity and disability in a similar way. There has been correlation between pain and depressive symptoms and between catastrophizing and disability ${ }^{23}$.

The study had no control group, was not randomized or blind for evaluation and has not analyzed individual effects of psychological therapy and biofeedback interventions.

Again, it is observed a question about the superiority of graded exposure over graded activity to change self-efficacy and fear of pain and movement avoidance, pain and disability beliefs. When a therapy is more broadly tested (more studies) and with more rigorous designs, often "initial certainties" are weakened, which requires a set of studies with robust designs to clarify questions. This is supposed to be the current status of in vivo exposure, graded activity and education to change beliefs and disability of chronic low back pain patients, which justifies further studies on the subject.

\section{CONCLUSION}

Most studies of this review have compared in vivo exposure and graded activity. Just one study has evaluated the effectiveness of education before exposure and has observed beneficial effects of education alone. Sessions content, number and duration, accurate description of performed movement, how many times the movement was performed, how were educative sessions or the session to understand the fear of pain, catastrophizing, immobility and disability cycle were not adequately described; also the training of interventionists was not adequately explained. In light of the few number of publications on the subject, advantages or the way to perform graded exposure in low back pain patients are still not clear.

\section{REFERENCES}

1. Pincus T, McCracken LM. Psychological factors and treatment opportunities in low back pain. Best Pract Res Clin Rheumatol. 2013;27(5):625-35.

2. Vlaeyen JW, de Jong J, Geilen M, Heuts PH, van Breukelen G. The treatment of fear of movement/(re)injury in chronic low back pain: Further evidence on the effectiveness of exposure in vivo. Clin J Pain. 2002;18(4):251-61.

3. de Jong JR, Vlaeyen JW, Onghena P, Goossens ME, Geilen M, Mulder H. Fear of movement/(re)injury in chronic low back pain: education or exposure in vivo as mediator to fear reduction? Clin J Pain. 2005;21(1):9-17; discussion 69-72.

4. Grotle M, Vøllestad NK, Brox JI. Clinical course and impact of fear-avoidance beliefs in low back pain: prospective cohort study of acute and chronic low back pain: II. Spine. 2006;31(9):1038-46.

5. Vlaeyen JW, De Jong JR, Onghena P, Kerckhoffs-Hanssen M, Kole-Snijders AM. Can pain-related fear be reduced? The application of cognitive-behavioural exposure in vivo. Pain Res Manag. 2002;7(3):144-53.

6. Leeuw M, Goossens ME, van Breukelen GJ, de Jong JR, Heuts PH, Smeets RJ, et al. Exposure in vivo versus operant graded activity in chronic low back pain patients: results of a randomized controlled trial. Pain. 2008;138(1)192-207.

7. Vlaeyen JW, Linton SJ. Fear-avoidance model of chronic musculoskeletal pain: 12 years on. Pain. 2012;153(6):1144-7.

8. Crombez G, Eccleston C, Van Damme S, Vlaeyen JW, Karoly P. Fear-avoidance model of chronic pain: the next generation. Clin J Pain. 2012;28(6):475-83.

9. Vlaeyen JW, MPhil SJ, Morley Linton SJ, Boersma K, Jong JD. Pain-related fear: exposure-based treatment of chronic pain. Seatle: IASP; 2012.

10. Lucchetti G, Oliveira AB, Mercante JP, Peres MF. Anxiety and fear-avoidance in musculoskeletal pain. Curr Pain Headache Rep. 2012;16(5):399-406.

11. Vlaeyen JW, de Jong J, Geilen M, Heuts PH, van Breukelen G. Graded exposure in vivo in the treatment of pain-related fear: A replicated single-case experimental design in four patients with chronic low back pain. Behav Res Ther. 2001;39(2):151-66.

12. Lethem J, Slade PD, Troup JD, Bentley G. Outline of a fear-avoidance model of 
exaggerated pain perception--I. Behav Res Ther. 1983;21(4):401-8.

13. Slade PD, Troup JD, Lethem J, Bentley G. The fear-avoidance model of exaggerated pain perception--II. Behav Res Ther. 1983;21(4):409-16.

14. Vlaeyen JW, Linton SJ. Fear-avoidance and its consequences in chronic musculoskeletal pain: a state of the art. Pain. 2000;85(3):317-32.

15. Leeuw M, Goossens ME, Linton SJ, Crombez G, Boersma K, Vlaeyen JW. The fear-avoidance model of musculoskeletal pain: current state of scientific evidence. J Behav Med. 2007;30(1):77-94

16. Woods MP, Asmundson GJ. Evaluating the efficacy of graded in vivo exposure for the treatment of fear in patients with chronic back pain: a randomized controlled clinical trial. Pain. 2008;136(3)271-80.

17. Denison E, Asenlöf P, Sandborgh M, Lindberg P. Musculoskeletal pain in primary health care: subgroups based on pain intensity, disability, self-efficacy, and fear-avoidance variables. J Pain. 2007;8(1):67-74.

18. Costa Lda C, Maher CG, McAuley JH, Hancock MJ, Smeets RJ. Self-efficacy is more important than fear of movement in mediating the relationship between pain and disability in chronic low back pain. Eur J Pain. 2011;15(2):213-9.

19. Woby SR, Urmston M, Watson PJ. Self-efficacy mediates the relation between pain-related fear and outcome in chronic low back pain patients. Eur J Pain. 2007;11(7):711-8.

20. Salvetti Mde G, Pimenta CA, Braga PE, Corrêa CF. [Disability related to chronic low back pain: prevalence and associated factors]. Rev Esc Enferm USP. 2012;46(Spec $\left.\mathrm{n}^{\circ}\right): 16-23$. Portuguese.

21. de Moraes Vieira EB, de Góes Salvetti M, Damiani LP, de Mattos Pimenta CA. Self-efficacy and fear avoidance beliefs in chronic low back pain patients: coexistence and associated factors. Pain Manag Nurs. 2014;15(3):593-602.
22. Crombez G, Vervaet L, Lysens R, Baeyens F, Eelen P. Avoidance and confrontation of painful, back-straining movements in chronic back pain patients. Behav Modif. 1998;22(1):62-77.

23. George SZ, Wittmer VT, Fillingim RB, Robinson ME.Comparison of graded exercise and graded exposure clinical outcomes for patients with chronic low back pain. J Orthop Sports Phys Ther. 2010;40(11):694-704.

24. Pincus T, Smeets RJ, Simmonds MJ, Sullivan MJ. The fear avoidance model disentangled: improving the clinical utility of the fear avoidance model. Clin J Pain. 2010;26(9):739-46.

25. Salvetti MG, Kurita GP, Longo ES, Pimenta CA. Efeitos da intervenção exposição ao vivo e atividades graduais sobre a incapacidade e a crença de medo e evitaçăo em pacientes com dor lombar crônica. Rev Bras Terap Comport Cogn. 2012;14(3):123-33.

26. da Costa Santos CM, de Mattos Pimenta CA, Nobre MR. The PICO strategy for the research question construction and evidence search. Rev Lat Am Enfermagem. 2007;15(3):508-11.

27. Boersma K, Linton S, Overmeer T, Jansson M, Vlaeyen J, de Jong J. Lowering fear-avoidance and enhancing function through exposure in vivo. A multiple baseline study across six patients with back pain. Pain. 2004;108(1-2):8-16.

28. Linton SJ, Boersma K, Jansson M, Overmeer T, Lindblom K, Vlaeyen JW. A randomized controlled trial of exposure in vivo for patients with spinal pain reporting fear of work-related activities. Eur J Pain. 2008;12(6):722-30.

29. George SZ, Zeppieri G. Physical therapy utilization of graded exposure for patients with low back pain. J Orthop Sports Phys Ther. 2009;39(7):496-505.

30. Vlaeyen JW, de Jong J, Sieben J, Crombez G. Graded exposure in vivo for pain-related fear. In: Gatchel DCTRJ (editor). Psychological approaches to pain management: a practitioner's handbook $2^{\text {nd }}$ ed. New York, NY, US: Guilford Press; 2002. 210-33p. 